\title{
Enhanced cAMP Response Element-Binding Protein Activity Increases Neuronal Excitability, Hippocampal Long-Term Potentiation, and Classical Eyeblink Conditioning in Alert Behaving Mice
}

\author{
Agnès Gruart, ${ }^{1}$ Eva Benito, ${ }^{2}$ José M. Delgado-García, ${ }^{1}$ and Angel Barco ${ }^{2}$ \\ ${ }^{1}$ Division of Neurosciences, Pablo de Olavide University, Seville 41013, Spain, ${ }^{2}$ Instituto de Neurociencias de Alicante (Universidad Miguel Hernández- \\ Consejo Superior de Investigaciones Científicas), Campus de Sant Joan, Sant Joan d'Alacant, Alicante 03550, Spain
}

\begin{abstract}
The activity-regulated transcription factor cAMP response element-binding protein (CREB) is an essential component of the molecular switch that controls the conversion of short-term into long-term forms of plasticity, including those underlying long-term memory. Previous research in acute brain slices of transgenic animals expressing constitutively active CREB variants has revealed that enhancing CREB activity increases the intrinsic excitability of neurons and facilitates the late phase of long-term potentiation (LTP) in the Schaffer collateral pathway. Here, we report similar changes in plasticity at the Schaffer collateral pathway in alert behaving mice. Forebrain expression of a strong constitutively active CREB variant, VP16-CREB, enhanced in vivo LTP evoked in the Schaffer collateral pathway and caused significant changes in the input/output curve and paired-pulse facilitation in CA3-CA1 synapses, which could be explained by the increased excitability of hippocampal pyramidal neurons. In addition, classical eyeblink conditioning in transgenic mice and control littermates showed larger conditioned responses in mutant mice that were associated to a transient increase in the acquisition rate and in the concomitant learning-dependent change in synaptic strength. The sustained chronic activation of CREB activity, however, impaired the performance in this task. Our experiments demonstrate that the sustained enhancement of CREB function alters the physiology and plasticity of hippocampal circuits in behaving animals and that these changes have important consequences in associative learning.
\end{abstract}

\section{Introduction}

The transcription factor cAMP response element-binding protein (CREB) is thought to be an essential component of the molecular switch that controls the conversion of short-term forms of plasticity into long-term forms, including those underlying longterm memory formation (Lonze and Ginty, 2002; Barco and Marie, 2011). In addition to the classical role of CREB in synaptic plasticity, studies in the last five years have demonstrated a novel role for CREB in the control of intrinsic neuronal excitability that may also contribute importantly to learning and memory processes (Benito and Barco, 2010).

Our previous research on bitransgenic mice expressing a constitutively active CREB (caCREB) variant with strong activity as

Received Sept. 11, 2012; revised 0ct. 2, 2012; accepted 0ct. 5, 2012.

Author contributions: A.G., J.M.D.-G., and A.B. designed research; A.G., E.B., J.M.D.-G., and A.B. performed research; A.G., E.B., J.M.D.-G., and A.B. analyzed data; A.G., J.M.D.-G., and A.B. wrote the paper.

The work was supported by Ministry of Science and Innovation Grants BFU2008-0899 (J.M.D.-G.), BFU200803390 (A.G.), and BFU2008-00611 (A.B.). The research leading to these results also received funding from the Seventh Framework Program of the European Community (FP7/2007-2013) under Grant Agreement 201714 (DEVANX). We thank M. Esteban, R. Olivares, and M. Sánchez-Enciso for their technical assistance.

Correspondence should be addressed to Agnès Gruart, Division of Neurosciences, Pablo de Olavide University, 41013 Seville, Spain. E-mail: agrumas@upo.es.

E. Benito's current address: European Neuroscience Institute (ENI), DZNE Göttingen, Grisebachstraße 5. 37077, Göttingen, Germany.

DOI:10.1523/JNEUROSCI.4339-12.2012

Copyright $\odot 2012$ the authors $\quad 0270-6474 / 12 / 3217431-11 \$ 15.00 / 0$ transcriptional transactivator, referred to as VP16-CREB, revealed that chronic boosting of CREB activity has a dramatic effect on neuronal gene expression and physiology. VP16-CREB expression in CA1 pyramidal neurons enhanced intrinsic excitability (Lopez de Armentia et al., 2007) and facilitated longlasting long-term potentiation (L-LTP) in the Schaffer collateral pathway (Barco et al., 2002; Alarcon et al., 2006). These results have been confirmed in other gain-of-function studies using caCREB variants (Marie et al., 2005; Suzuki et al., 2011) and, together with loss-of-function experiments (Pittenger et al., 2002; Jancic et al., 2009), have demonstrated that CREB-dependent gene expression bidirectionally modulates both intrinsic and synaptic plasticity in hippocampal neurons. Importantly, all the electrophysiological experiments referred to above were performed in acute brain slices, which constrain the timeframe of the experiments and can introduce some artifacts resulting from the altered circuitry. These findings have led to novel questions concerning the role of CREB in plasticity in behaving animals, the reproducibility of the findings in intact hippocampal circuits, and the interaction between CREB-dependent changes in synaptic and intrinsic plasticity and different forms of associative learning.

To clarify these issues, we investigated here the changes in synaptic transmission and plasticity in the Schaffer collateral pathway in alert behaving mice inducibly expressing VP16CREB in hippocampal neurons. The use of the tetracycline transactivator (tTA) system for regulatable transgenesis, in which the 
removal of the drug doxycycline (dox) from the mouse diet triggers transgene expression within a few days, allowed us to investigate hippocampal physiology in the same animals before and after transgene induction. We found that transgene induction caused significant changes in input/output (I/O) curves and paired-pulse facilitation (PPF) of field EPSPs (fEPSPs) evoked at the CA3-CA1 synapse supporting an increase in the excitability of hippocampal pyramidal neurons. These changes correlated with an enhancement of LTP in CA3-CA1 synapses in response to high-frequency stimulation (HFS) of Schaffer collaterals. Bitransgenic mice were also subjected to classical conditioning of eyelid responses determined by changes in the electromyographic (EMG) activity of the orbicularis oculi muscle. Mutant mice presented larger conditioned responses and a transient facilitation of eyeblink conditioning and concurrent potentiation of CA3-CA1 synapses, although sustained transgene activation eventually led to memory deficits in this task. In summary, our experiments demonstrate that the sustained enhancement of CREB function alters the physiology and plasticity of hippocampal circuits in behaving animals and that these changes have important consequences in hippocampal-dependent behaviors.

\section{Materials and Methods}

Animals. Experiments were performed in bitransgenic pCaMKII $\alpha-\mathrm{tTA} /$ tetO-VP16-CREB ${ }^{\text {high }}$ mature (3/5-month-old; 25-30 g) male mice generated on a C57BL6/J background (Barco et al., 2002; Lopez de Armentia et al., 2007). For simplicity, these mice are referred to here as VP16CREB mice. As control, we used littermate mice carrying the single transgene pCaMKII $\alpha$-tTA (Mayford et al., 1996), tetO-VP16-CREB, or no transgene. Mice were bred and maintained using a mouse diet supplemented with dox $(40 \mathrm{mg} / \mathrm{kg})$. We replaced the dox-supplemented diet by regular mouse diet at specific times before or during experimentation. Previous experiments have demonstrated that, under this regimen, transgene expression starts 3-4 d after dox removal and reaches a plateau after 3 additional days (Barco et al., 2002, 2005). Mice were bred at the Institute of Neurosciences Animal House (Spanish National Research Council) and transferred to the Pablo de Olavide University Animal House 2 weeks before the beginning of the experiments. Animals were kept on a $12 \mathrm{~h}$ light/dark cycle with constant ambient temperature $(21 \pm$ $\left.1.5^{\circ} \mathrm{C}\right)$ and humidity $(55 \pm 10 \%)$. Food and water were available ad libitum. Mice were switched from shared cages (six animals per cage) to individual cages after surgery. Experiments were performed in accordance with the guidelines of the European Union (2003/65/CE) and Spanish regulations (BOE 252/34367-91, 2005) for the use of laboratory animals in chronic studies. Experimental protocols were also approved by the Ethics Committee of the Pablo de Olavide University. Unless otherwise indicated, a total of 10 successful animals were used per experimental group. We considered successful animals those presenting fEPSPs and EMG recordings that did not deteriorate across the whole experimental protocol.

Surgical preparation of experimental animals. Mice were anesthetized with $0.8-1.5 \%$ isoflurane, supplied from a calibrated Fluotec 5 (FluotecOhmeda) vaporizer, at a flow rate of $1-2 \mathrm{~L} / \mathrm{min}$ oxygen (AstraZeneca) and delivered by a mouse anesthesia mask (David Kopf Instruments). Mice were implanted with stimulating electrodes in the right Schaffer collateral/commissural pathway of the dorsal hippocampus $[2 \mathrm{~mm}$ lateral and $1.5 \mathrm{~mm}$ posterior to bregma and $1-1.5 \mathrm{~mm}$ from the brain surface (Paxinos and Franklin, 2004)] and with a recording electrode aimed at the right CA1 stratum radiatum $(1.2 \mathrm{~mm}$ lateral and $2.2 \mathrm{~mm}$ posterior to bregma and $1-1.5 \mathrm{~mm}$ from the brain surface). These hippocampal electrodes were made from $50-\mu \mathrm{m}$, Teflon-coated, tungsten wire (Advent Research). Electrodes were surgically implanted in the CA1 area using as a guide the field potential depth profile evoked by paired ( 40 ms of interval) pulses presented at the ipsilateral Schaffer collateral pathway. The recording electrode was fixed at the site in which a reliable monosynaptic fEPSP was recorded (see Fig. 1A). Animals selected for classical eyeblink conditioning were also implanted with stimulating electrodes on the contralateral (left) supraorbital nerve and with recording electrodes in the contralateral (left) orbicularis oculi muscle. These electrodes were made from $50-\mu \mathrm{m}$, Teflon-coated, annealed stainless steel wire (A-M Systems). A bare silver wire affixed to the bone served as ground. All the implanted wires were soldered to two four-pin sockets (RS Amidata) and fixed to the skull with dental cement (for details, see Gruart et al., 2006).

Recording and stimulation procedures. Recording sessions were performed with three animals at a time. Animals were placed in separate, small $(5 \times 5 \times 10 \mathrm{~cm})$ plastic chambers located inside a larger Faraday box $(30 \times 30 \times 20 \mathrm{~cm})$. The EMG activity of the orbicularis oculi muscle was recorded with Grass P511 differential amplifiers (Grass-Telefactor) at a bandwidth of $0.1 \mathrm{~Hz}$ to $10 \mathrm{kHz}$, whereas fEPSP recordings were also made with Grass P511 differential amplifiers through a high-impedance probe $(2 \times 1012 \Omega, 10 \mathrm{pF})$.

For I/O curves (see Fig. 1), animals were stimulated at the Schaffer collaterals with paired pulses ( $40 \mathrm{~ms}$ of interstimulus interval) at increasing intensities $(0.02-0.4 \mathrm{~mA})$. To avoid any cumulative effect, intensities and intervals were presented at random, at a rate of 1 every $20 \mathrm{~s}$. To determine PPF in the two groups of animals (see Fig. 2), we checked the effects of paired pulses at different (10,20, 40, 100, 200, and $500 \mathrm{~ms}$ ) interstimulus intervals and intensities corresponding to $30-40 \%$ of the amount necessary to evoke a saturating response. In all cases, the pair of pulses of a given intensity was repeated at least five times with time intervals $\geq 30 \mathrm{~s}$, to avoid as much as possible interference with slower short-term potentiation (augmentation) or depression processes (Zucker and Regehr, 2002).

We also checked LTP evoked by HFS in controls and mutant mice. fEPSP baseline values were collected 15 min before LTP induction using paired (40 ms interstimulus interval) $100 \mu \mathrm{s}$, square, biphasic pulses. Pulse intensity was set at $35 \%$ (see Fig. 3) or at $50 \%$ (see Fig. 4 ) of the amount necessary to evoke a maximum fEPSP response (0.05-0.15 mA), that is, below the threshold for evoking a large population spike (Gureviciene et al., 2004; Gruart et al., 2006). An additional criterion for selecting stimulus intensity was that the second stimulus should evoke a larger $(>20 \%)$ fEPSP than the first (Bliss and Gardner-Medwin, 1973). For LTP induction, animals were presented with an HFS session consisting of five $200 \mathrm{~Hz}, 100 \mathrm{~ms}$ trains of pulses at a rate of 1/s. This protocol was presented six times, at intervals of $1 \mathrm{~min}$. Thus, a total of 600 pulses were presented during an HFS session. To avoid evoking large population spikes and/or the appearance of EEG seizures, the stimulus intensity during HFS was set at the same as that used for generating baseline recordings. Animals presenting afterdischarges or motor seizures after the HFS protocol (as checked by online EEG recordings and visual observation of the stimulated animal) were excluded from the study. After the HFS session, the same paired-pulse stimuli $(40 \mathrm{~ms}$ interstimulus interval) were presented every $20 \mathrm{~s}$ for $30 \mathrm{~min}$ and for $15 \mathrm{~min}$ the 2 following days (for details, see Gruart et al., 2006; Madroñal et al., 2007).

Classical conditioning of eyelid responses. Classical eyeblink conditioning was achieved using a trace paradigm (Gruart et al., 2006). For this, a tone $(20 \mathrm{~ms}, 2.4 \mathrm{kHz}, 85 \mathrm{~dB})$ was presented as a conditioned stimulus (CS). The unconditioned stimulus (US) consisted of a $500 \mu \mathrm{s}, 3 \times$ threshold, square, cathodal pulse applied to the supraorbital nerve. The US started $500 \mathrm{~ms}$ after the end of the CS. In total, two habituation, 10 conditioning, and five extinction or two habituation and 14 conditioning sessions were performed. A conditioning session consisted of 60 CS-US presentations and lasted $\sim 30 \mathrm{~min}$. For a proper analysis of the evoked conditioned responses, the CS was presented alone in $10 \%$ of the cases. CS-US presentations were separated at random by $30 \pm 5 \mathrm{~s}$. Animals received just one training session per day. For habituation and extinction sessions, only the CS was presented, also for 60 times per session, at intervals of $30 \pm 5 \mathrm{~s}$. As criteria, we considered as a conditioned response the presence, during the CS-US interval, of EMG activity lasting $>10 \mathrm{~ms}$ and initiated $>50 \mathrm{~ms}$ after CS onset. In addition, the integrated EMG activity recorded during the CS-US interval had to be at least 2.5 times greater than the averaged activity recorded immediately before CS presentation (Porras-García et al., 2005). fEPSPs were evoked at the CA3CA1 synapse during habituation, conditioning, and extinction sessions by a single $100 \mu$ s, square, biphasic (negative-positive) pulse applied to 
A Stratum cellulare

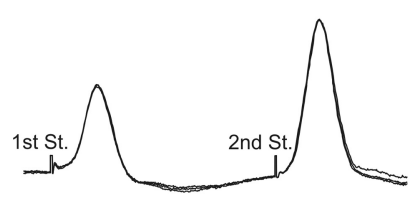

B

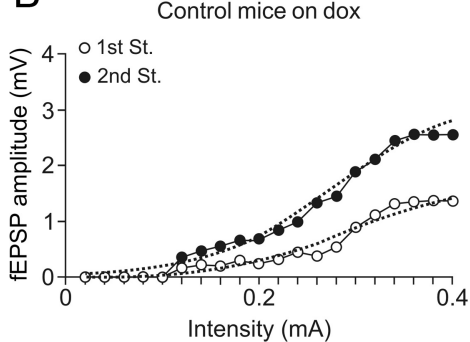

$\mathrm{E}$

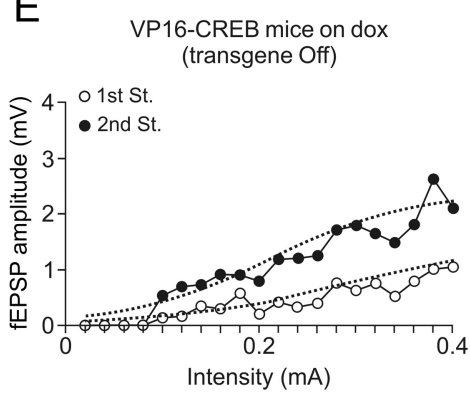

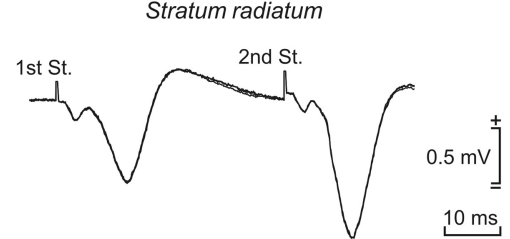

C

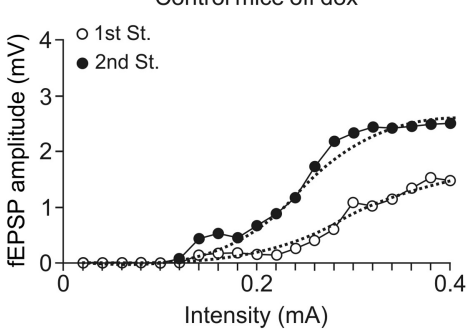

$\mathrm{F}$
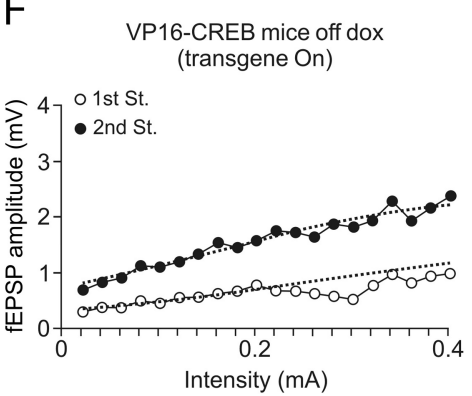

D Control mice

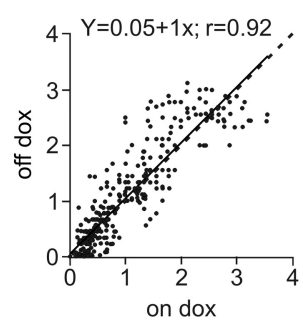

G

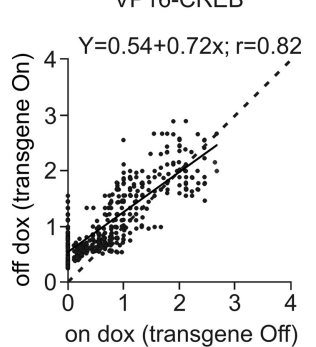

Figure 1. I/ 0 curves in VP16 -CREB and control mice. $A$, Representative examples of fEPSPs ( 3 overlapping records) evoked in the stratum cellulare after paired pulses ( $40 \mathrm{~ms}$ of interpulse interval) presented to Schaffer collaterals (left) and in the stratum radiatum (right). $\boldsymbol{B}, \boldsymbol{C}, \mathrm{I} / \mathbf{0}$ curves evoked at the CA1-CA3 synapse of control mice $(n=10)$ before $(\boldsymbol{B})$ and after $(\boldsymbol{C})$ dox removal. Note that no significant $(p>0.05$ ) differences were observed. Stimulus consisted of paired pulses ( $40 \mathrm{~ms}$ of interstimulus interval) presented at increasing intensities in $20 \mu \mathrm{A}$ steps. White circles indicate fEPSP amplitudes evoked by the first pulse, and black circles indicate fEPSPs evoked by the second pulse. Each circle represents the mean value computed from five stimulus presentations (10 animals per group). $D$, A scatter plot illustrating fEPSP values evoked by the paired pulses in control mice fed with dox ( $x$-axis, on dox) and after dox removal ( $y$-axis, off dox). The best linear fit is illustrated. $\boldsymbol{E}, \boldsymbol{F}, \mathrm{I} / \mathbf{0}$ curves in the same hippocampal synapse of bitransgenic mice $(n=10)$ before $(\boldsymbol{E})$ and after $(\boldsymbol{F})$ dox removal. Note the increased excitability evoked in mutant mice after dox removal. $\boldsymbol{G}, \mathrm{A}$ scatter plot illustrating fEPSP values evoked by the paired pulses in VP16-CREB mice fed with dox [x-axis; on dox (transgene 0ff)] and after dox removal [y-axis, off dox (transgene 0n)]. Note that values were shifted upward and that the slope of the linear fit was $<1(b=0.72)$. In $\boldsymbol{C}$ and $\boldsymbol{F}$, dox was removed from mouse diet $5 \mathrm{~d}$ before recording the $\mathrm{I} / 0$ curve. The best sigmoid fit to data illustrated in $\boldsymbol{B}, \boldsymbol{C}, \boldsymbol{E}$, and $\boldsymbol{F}$ is represented for each group of animals $(r \geq 0.98 ; p<0.001)$.

Schaffer collaterals $300 \mathrm{~ms}$ after CS presentation. Stimulus intensities ranged from 0.05 to $0.35 \mathrm{~mA}$.

Histological study of electrode location. At the end of the experiments, mice were deeply reanesthetized ( $4 \%$ chloral hydrate solution, $10 \mathrm{ml} / \mathrm{kg}$ ) and perfused transcardially with saline and $4 \%$ phosphate-buffered paraformaldehyde. Their brains were removed, postfixed overnight at $4^{\circ} \mathrm{C}$, and cryoprotected in $30 \%$ sucrose in PBS. To determine the location of implanted electrodes, dorsal hippocampus sections were obtained in a microtome (Leica) at $50 \mu \mathrm{m}$, mounted on glass slides, and stained with $0.1 \%$ toluidine blue. Double immunohistochemistry, using anti-VP16 and anti-c-fos antibodies (Santa Cruz Biotechnology), was performed as described previously by some of us (Barco et al., 2002).

Data storage and analyses. EMG recordings, hippocampal fEPSPs, and $1 \mathrm{~V}$ rectangular pulses corresponding to paired-pulse presentations, HFS, and CS and US presentations were stored digitally on a computer through an analog/digital converter (CED 1401 Plus; Cambridge Electronic Design). Data were analyzed offline for quantification of fEPSP and EMG recordings with the Spike 2 (Cambridge Electronic Design) program. The slope of evoked fEPSPs was computed as the first derivative (volts per second) of fEPSP recordings (volts). Depending on the experiment, $5-15$ successive fEPSPs were averaged, and the mean value of the slope during the rise-time period (i.e., the period of the slope between the initial $10 \%$ and the final $10 \%$ of the fEPSP) was determined. The integrated EMG activity (expressed in microvolts $\times$ seconds) of the orbicularis oculi muscle was quantified following procedures described previously (Porras-García et al., 2005). Computed results were processed for statistical analysis using the SigmaStat for Windows package. Data are always represented as the mean \pm SEM. Acquired data were analyzed using a two-way ANOVA, with days as repeated measure and with a contrast analysis for an additional study of significant differences.

\section{Results}

\section{Chronic CREB activation alters the I/O curve and PPF}

The functional capabilities of hippocampal synapses were investigated in alert behaving bitransgenic mice and control littermates. The electrical stimulation of Schaffer collaterals in behaving mice evokes a large positive wave, with a latency of 3.5-4 ms when recorded near the pyramidal cell layer (stratum cellular; Fig. $1 A$, left set of records) or a negative wave, with similar amplitude and latency, when the recording electrode is located on the apical dendrites of the CA1 pyramidal cells in the stratum radiatum (Fig. $1 A$, right set of records) (Gruart et al., 2006). To characterize the impact of chronic activation of the CREB pathway on the functional properties of the CA3-CA1 synapse in vivo, we tested the facilitation evoked by the presentation of a pair of pulses to Schaffer collaterals in the same control and bitransgenic animals, before and after transgene induction.

First, we recorded the changes in fEPSP slopes evoked in the pyramidal CA1 area by paired-pulse ( $40 \mathrm{~ms}$ interval) stimulation in dox-treated mice (Fig. $1 B, E$ ). For control mice (Fig. 1B), the 
slope of fEPSPs evoked in the CA1 area by the first pulse (white circles) increased steadily with current strength (range of $0.02-0.4 \mathrm{~mA}$ in steps of $0.02 \mathrm{~mA}$ ) and presented a sigmoid shape $(r=0.97, p<$ 0.0001). fEPSPs evoked by the second pulse (black circles) also presented a sigmoid shape $(r=0.99, p<0.0001)$ and increased initially in parallel with fEPSPs evoked by the first pulse until stimuli was $>0.20 \mathrm{~mA}$. The fEPSP slopes evoked by the second stimulus were significantly larger than for the first stimulus $\left(F_{(19,171)}=\right.$ 8.42; $p<0.001)$. In bitransgenic mice fed with dox (transgene expression turned off), the fEPSPs evoked by the pair of pulses also presented sigmoid shapes (first fEPSPs, $r=0.98, p<$ 0.0001 ; second fEPSPs, $r=0.96, p<$ 0.0001 ) and had magnitudes similar to those observed in their littermate controls (Fig. $1 E ; F_{(19,171)}=12.59 ; p=0.06$ ). It is important to indicate that no significant differences were observed between curves evoked by the first $(p=0.48)$ and the second pulses in dox-treated bitransgenic and control mice.

Next, we removed dox from the mouse diet to switch on transgene expression in bitransgenic VP16-CREB mice. One week after dox removal, the change did not modify the I/O curves evoked in control mice by paired-pulse stimulation of the CA3-CA1 synapse (Fig. 1C) but increased significantly the excitability of the CA3-CA1 synapse in bitransgenic mice (Fig. $1 F$ ) compared with the results collected from these animals before dox removal $\left(F_{(19,171)}=25.33 ; p<0.001\right)$ and with those from control littermates after dox removal $\left(F_{(19,171)}=\right.$ $44.37 ; p<0.001)$. It should be noted that these changes in excitability were particularly apparent at lower stimulation intensities, which caused the curve in bitransgenic mice to flatten out and deviate from the sigmoid shape observed in control mice.

An important feature of this study is that it allows measuring electrical properties in the same animals before and after transgene induction. Figure 1, D and $G$, compares fEPSP amplitudes collected from mice treated with dox during the I/O study (on the $x$-axis) with the corresponding values after dox removal ( $y$-axis). These scatter plots show that fEPSP values collected from control mice were distributed around the diagonal (Fig. 1D), whereas the corresponding values from mutant mice were shifted upward and presented a (linear) slope $<1(b=0.72$; Fig. $1 G)$, in agreement with the proposed increase in excitability.

In parallel to the recording of $\mathrm{I} / \mathrm{O}$ values, we investigated $\mathrm{PPF}$ in the same group of VP16-CREB and control littermates. PPF is a form of short-term plasticity that has been associated with changes in neurotransmitter release (Zucker and Regehr, 2002; Gruart et al., 2006; Madroñal et al., 2007). In addition to the fixed $40 \mathrm{~ms}$ interstimulus interval used for the preparation of $\mathrm{I} / \mathrm{O}$ curves, we tested mice for enhancement of synaptic transmission evoked by PPF using a wide range of interstimulus intervals (from 10 to $500 \mathrm{~ms}$ ). Control animals presented a significant increase $\left(F_{(5,45)}=133.13 ; p<0.001\right)$ in response to the second pulse at short time intervals $(10,20$, and $40 \mathrm{~ms})$ that was not modified $(p=0.55$ ) by dox removal (Fig. $2 A, B$ ). VP16-CREB

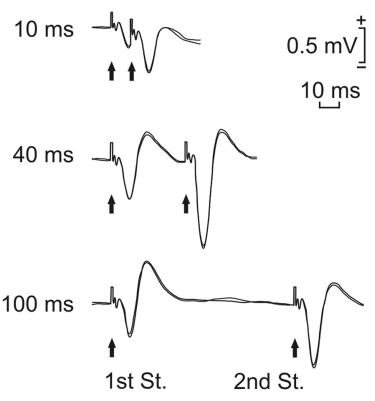

$\mathrm{D}$

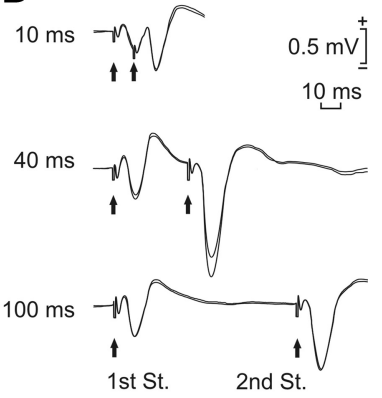

O Control mice on dox

$\triangle$ Control mice off dox

$\mathrm{ms}$

- VP16-CREB mice on dox
$\Delta$ VP16-CREB mice off dox

2nd St.
B $(p \leq 0.05)$ EPSP facilitation was evoked at short $(10-40 \mathrm{~ms})$ interstimulus interval sin control mice $(n=10)$. The data shown are 作 ive control mice at the indicated interstimulus intervals. $\boldsymbol{C}, \boldsymbol{D}$, Same data as in $\boldsymbol{A}$ and $\boldsymbol{B}$, collected from mutant (VP16-CREB) mice ant $(p<0.001)$ increase in PPF at $40 \mathrm{~ms}$ of interstimulus interval after dox removal.

mice fed with dox (transgene off) also presented a significant increase in the response to the second pulse at short time intervals $(10,20$, and $40 \mathrm{~ms})$, reaching values similar to those presented by the controls $\left(F_{(5,45)}=18.94 ; p<0.001\right)$. PPF was also observed in bitransgenic animals during VP16-CREB induction $\left(F_{(5,45)}=\right.$ 22.82; $p<0.001)$. Interestingly, dox removal produced a significant increase in PPF at $40 \mathrm{~ms}$ of interstimulus interval in mutant mice (Fig. 2C,D), suggesting a larger facilitation to paired-pulse stimulation in VP16-CREB-expressing animals at this interpulse interval.

LTP in the Schaffer collateral pathway in alert behaving mice is enhanced by VP16-CREB in a reversible manner

We also examined the evolution of fEPSPs evoked at the CA3CA1 synapse by pairs of stimuli (40 ms of interstimulus interval) presented before and after an HFS session in the same animals (Fig. $3 A, B$ ). The aim of this experiment was to determine whether this form of in vivo LTP was enhanced in VP16-CREB mice as observed in acute hippocampal slices (Barco et al., 2002). Stimulus intensity was set at $35 \%$ of the intensity necessary for evoking a maximum fEPSP response. The HFS session induced an LTP potentiation of fEPSPs evoked by the first pulse presented to the CA3-CA1 synapse in control animals $\left(F_{(14,126)}=0.28 ; p<\right.$ $0.01)$. This form of LTP lasted $<24 \mathrm{~h}$ in control mice, because the test performed $24 \mathrm{~h}$ after the HFS session did not indicate significant $(p=0.12)$ differences with baseline records. Bitransgenic mice also presented a significant $(p<0.01)$ LTP for fEPSPs evoked by the first pulse just after the HFS session but not $24 \mathrm{~h}$ after it $(p=0.08)$. The LTP evoked by the first pulse in mutant mice was significantly $\left(F_{(14,168)}=1.88 ; p<0.05\right)$ larger than that evoked in control mice (Fig. $3 B$, plus signs). Long-term potentiation was also evident for fEPSPs evoked by the second pulse in 
A

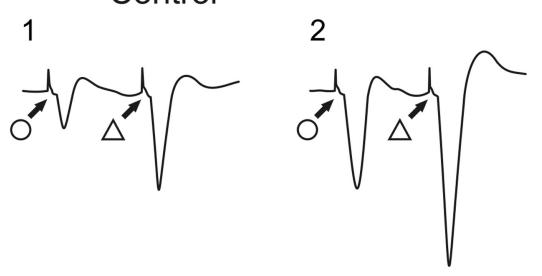

\section{VP16-CREB}

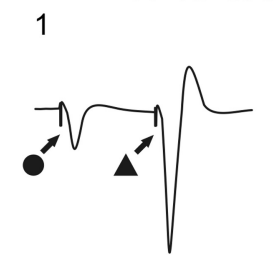

B

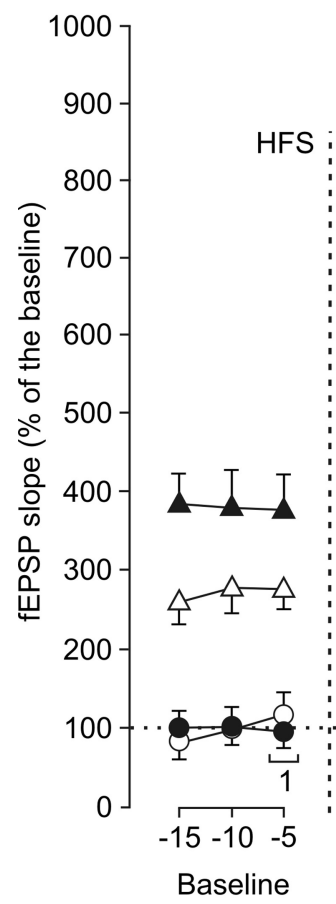

2

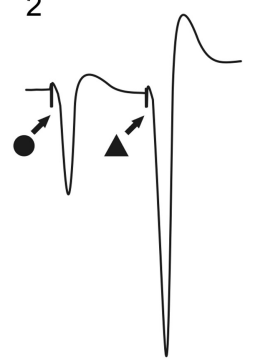

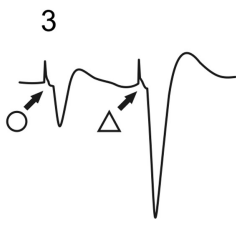

$0.5 \mathrm{mV}$

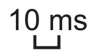

3

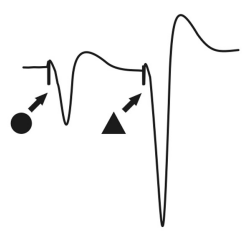

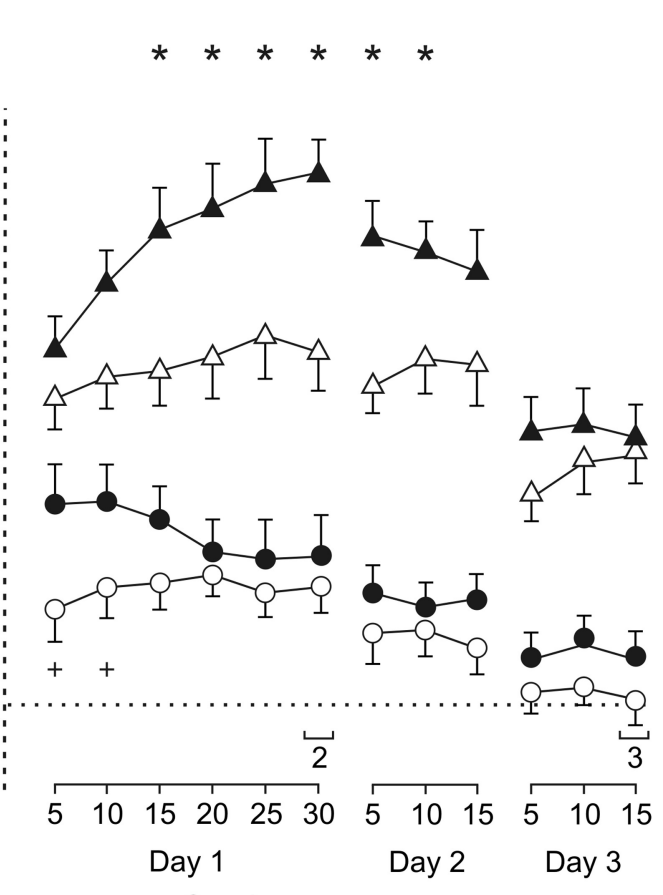

Sessions

Figure 3. Long-term potentiation evoked at the CA3-CA1 synapse with HFS of low (35\%) intensity. A, Representative paired (40 ms of interval) fEPSPs recorded in the hippocampal CA1 area from control (white circles and triangles) and mutant (VP16CREB; black circles and triangles) mice before (1, baseline) and 5-30 min (2) and $48 \mathrm{~h}$ (3) after HFS of Schaffer collaterals. HFS was set at $35 \%$ of the intensity (milliamperes) necessary to evoke a maximum fEPSP response. For comparative purposes, fEPSP amplitudes have been adapted to baseline value in control mice (100\%). $\boldsymbol{B}$, Graphs illustrating the time course of changes in fEPSPs (mean \pm SEM) after HFS stimulation of the Schaffer collaterals in the two groups ( $n=13$ animals per group) of animals. The HFS train was presented after 15 min of baseline recordings, at the time indicated by the dashed line. fEPSP slopes are expressed as a percentage of the baseline (100\%) slope. Both groups of animals presented a significant $(p<0.01)$ and long-lasting $(\sim 24 \mathrm{~h})$ increase in fEPSP slopes after HFS. In addition, significant differences between control and mutant animals were observed in the slopes of fEPSP evoked by the first $\left({ }^{+} p<0.01\right)$ and the second $\left({ }^{*} p \leq 0.05\right)$ pulses.

both groups of animals. The LTP evoked by the second pulse in fEPSP slopes lasted for $>24 \mathrm{~h}$ in control animals $\left(F_{(14,126)}=6.70\right.$; $p<0.001)$, as well as in mutant mice $(p<0.001)$. LTP evoked by the second pulse in mutant mice was, however, significantly $\left(F_{(14,168)}=2.508 ; p<0.01\right)$ larger than that evoked in control littermates ( $p \leq 0.04$; Fig. $3 B$, asterisks). In this regard, it should be pointed out that no significant difference $(p \geq 0.07)$ was observed between the PPF evoked in both groups of mice for baseline records (Fig. 3B).

In a following set of experiments aimed to confirm this enhancement of LTP and to explore the reversibility of the phenotype, we checked whether HFS sessions applied at $50 \%$ of the intensity necessary to evoke a maximum fEPSP response would elicit a larger and longer-lasting LTP in VP16CREB-expressing mice than in control mice. As shown in Figure 4A, the time of dox removal from the mouse diet during experimentation defined four experimental groups, referred as groups 1-4. The same LTP protocol was repeated twice $18 \mathrm{~d}$ apart (LTP-1 and LTP-2). In agreement with our previous experiment, group 4 (Fig. 4, Transgene On, diamonds) showed during the first induction of LTP (days 7-9) a significantly $\left(F_{(42,378)}=3.314, p<0.001\right)$ larger and longer-lasting LTP than either one of its control groups (LTP-1; Fig. 4B, left). Three days after LTP induction, the four groups went back to dox-supplemented diet. Twelve days later, we reinitiated the protocol, but this time we removed dox from the diet of alternate groups (groups 1 and 3 rather than groups 2 and 4 ). During the second LTP experiment (days 28-30), group 3 was the only one showing significantly larger and longer-lasting LTP (LTP-2; Fig. $4 B$, right). The facilitation of LTP observed for group 4 during LTP-1 was reversed to normal levels in LTP-2 through transgene repression by dox. Together with the experiments described above, these results demonstrate that the expression of VP16-CREB in principal neurons causes a larger and longer-lasting Schaffer collateral LTP in response to HFS of CA3 axons. Importantly, this enhancement was tightly associated with transgene expression and disappeared during transgene repression by dox.

\section{Gross anatomy and VP16-CREB} expression in electrode-implanted mice The proper location of stimulating and recording electrodes in the hippocampus was checked by histological procedures at the end of the experiment (Fig. 5A). As expected, with the exception of the electrode track, the analysis revealed a normal hippocampal integrity in slices from both mutant and control mice. Indeed, it has been reported that the overactivation of the CREB pathway for short periods of time (days) does not evoke detectable changes in hippocampal anatomy or ultrastructure (Lopez de Armentia et al., 2007; Valor et al., 2010). Transgene expression was confirmed by immunostainings against the VP16 domain located in the $\mathrm{N}$ terminus of VP16-CREB. In agreement with a previous report (Barco et al., 2002), we observed strong transgene expression in the CA1 and DG sub- 


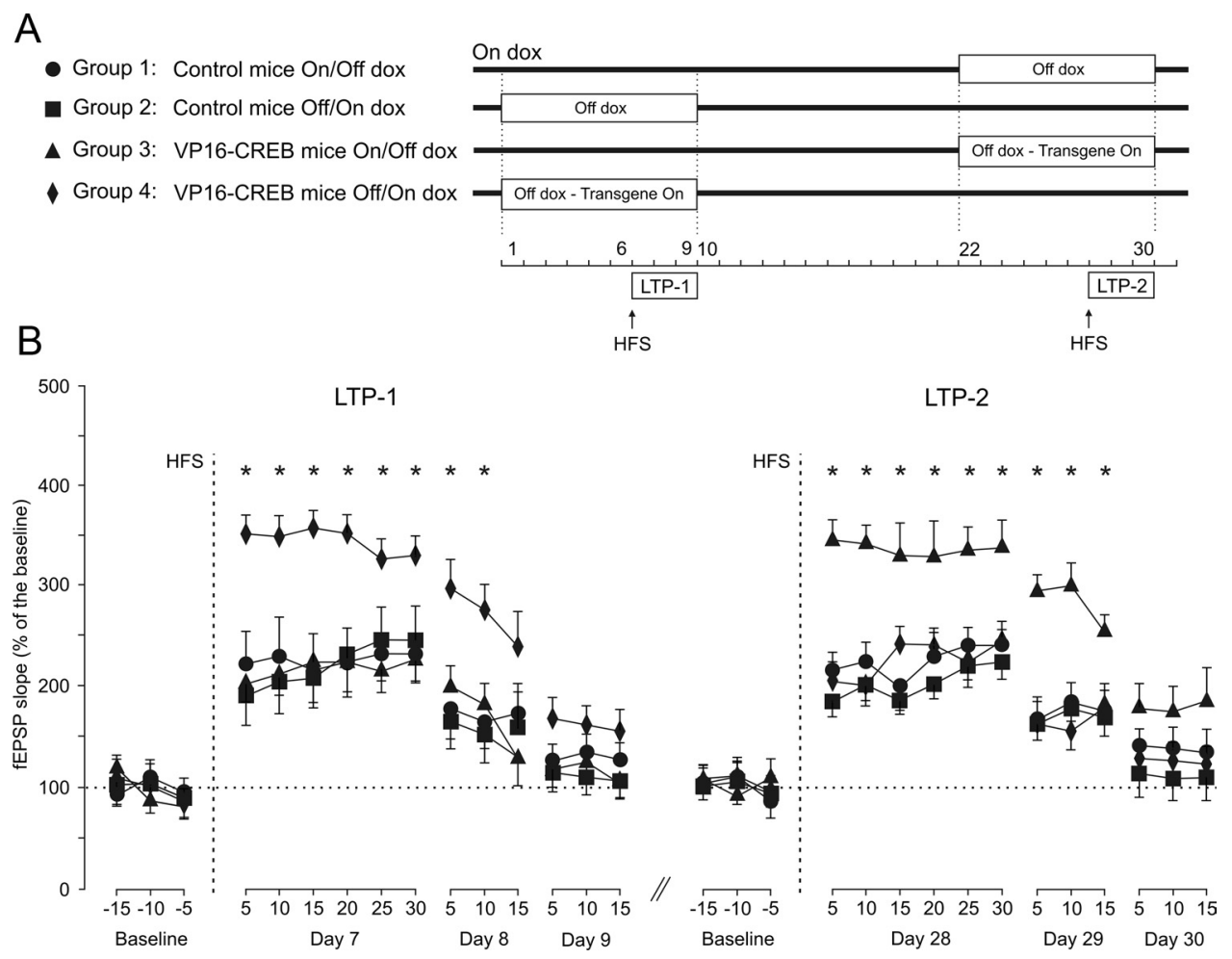

Figure 4. Long-term potentiation evoked at the CA3-CA1 synapses with HFS of high (50\%) intensity. $A$, Schematic representation of the experimental design. The timeline shows the period of transgene induction and the two HFS sessions. $\boldsymbol{B}$, Left shows the changes in fEPSPS (mean \pm SEM) after HFS stimulation of the Schaffer collaterals in the four groups ( $n=10$ animals per group) of animals: group 1, control on dox (black circles); group 2, control off dox (black squares); group 3, VP16-CREB on dox (black triangles); and group 4, VP16-CREB off dox (black diamonds). The HFS train was presented after 15 min of baseline recordings, at the time indicated by the dashed line, and was set at $50 \%$ of the intensity (milliamperes) necessary to evoke a maximum $\mathrm{fEPSP}$ response. fEPSP slopes are expressed as a percentage of the corresponding baseline (100\%) slope. Note that LTP evoked in group 4 (VP16 -CREB off dox) was significantly ${ }^{*} p \leq 0.01$ ) larger and longer-lasting that those evoked in the other three groups of mice. As indicated at the top, the diet administered to each of the four groups was switched, and the same HFS session was repeated $20 \mathrm{~d} \mathrm{later}$. As shown in the right set of graphs, group 3 (VP16 -CREB now with off dox) was the one presenting significantly larger and longer-lasting LTP ( ${ }^{*} p \leq 0.01$ ).

fields of the hippocampus, in striatum, and in specific layers of the cortex (Fig. 5B-D, green channel images). Importantly, double immunolabeling with antibodies against c-fos, a wellcharacterized CREB downstream gene associated with neuronal activation, demonstrated the efficacy of our transgene in driving CREB-dependent gene expression in vivo (Fig. $5 B-D$, red channel images). Similar images were obtained in slices from non-implanted mice at the same time after transgene induction (results not shown).

Transient facilitation of classical conditioning of eyelid responses and concomitant changes in strength of CA3-CA1 synapses by enhanced CREB activity

Next, we evaluated classical trace conditioning of eyeblink responses in independent groups of VP16-CREB and control mice using a trace paradigm (CS, tone; US, shock) with a $500 \mathrm{~ms}$ interval between the end of the CS and the beginning of the US (Fig. $6 A-C)$. This form of conditioning is associated with an increase in synaptic efficiency at the hippocampal CA3-CA1 synapse in alert behaving mice (Gruart et al., 2006). Electrodes implanted in the upper eyelid of experimental mice (Fig. 6B) did not disturb its normal kinematics and allowed the generation of spontaneous, reflex, and classically conditioned eyeblinks. The electrical stimulation $(2 \times$ threshold) of the supraorbital nerve evoked (in both mutant and control mice) an early EMG activation of the orbicularis oculi muscle at a latency of $\sim 5 \mathrm{~ms}$, followed by a second EMG activation, with a latency from the stimulus of $\sim 15 \mathrm{~ms}$ (data not illustrated). These successive muscle activations corre- spond to the R1 and R2 components already described in humans (Kugelberg, 1952) and other species of mammals, including mice (Gruart et al., 2006). The classical conditioning training consisted of $2 \mathrm{~d}$ of habituation, $10 \mathrm{~d}$ of conditioning, and $5 \mathrm{~d}$ of extinction (for additional details, see Materials and Methods). dox was removed from the mouse diet $5 \mathrm{~d}$ before starting habituation (Fig. $6 A$ ). Electrophysiological recordings in the orbicularis oculi muscle and the Schaffer collateral pathway accompanied behavioral assessment (Fig. 6C).

Spontaneous EMG activity of the orbicularis oculi muscle was slightly greater in mutants than in controls (Fig. $6 C$ ), but the differences were not significant $\left(F_{(16,144)}=1.30 ; p=0.20\right)$. In contrast, there were significant differences $(p=0.03)$ between integrated EMG areas (Fig. $6 D$ ) collected from conditioning sessions (fifth to ninth; Fig. 6E, asterisks). Because VP16-CREB is expressed in different parts of the neuronal circuit that regulates this response (Christian and Thompson, 2003), including neurons in the motor and premotor cortex and the hippocampus (Fig. 5), changes in excitability of those neurons could explain the increase in amplitude of the conditioned eyelid responses. Intriguingly, although the amplitude of conditioned responses was significantly larger in mutant animals, they generated lower percentages of conditioned responses than control littermates. In control mice, the percentage of conditioned responses increased steadily across conditioning sessions, reaching asymptotic values from the seventh conditioning session (Fig. $6 F$ ). From the second to the 10th conditioning sessions and from the first to the fourth extinction sessions, the percentage of conditioned responses was 
A
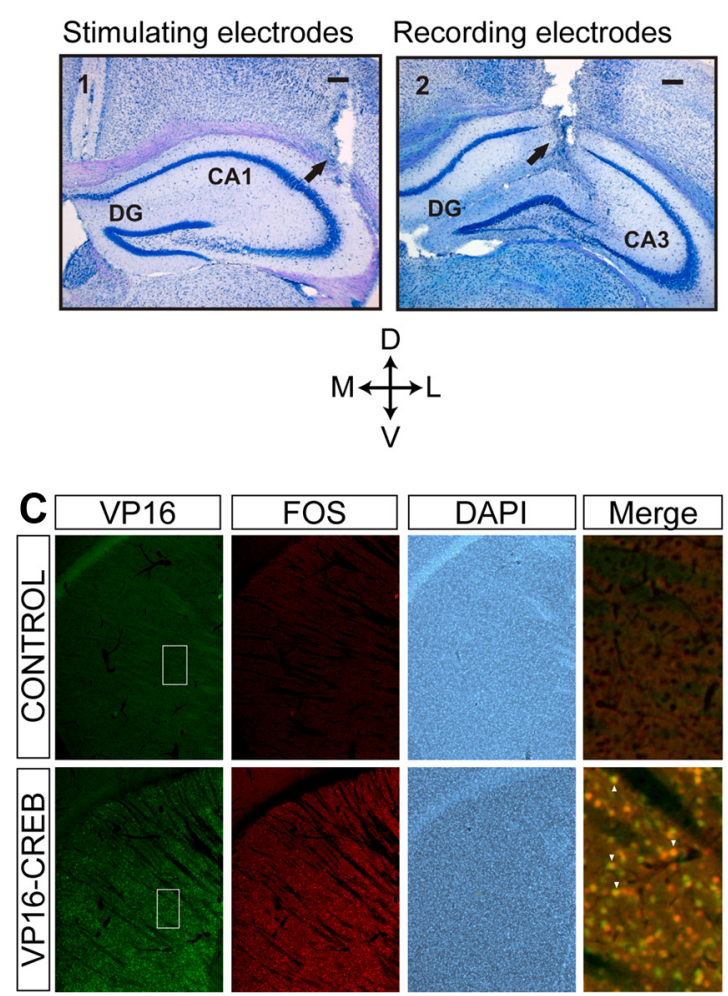

B
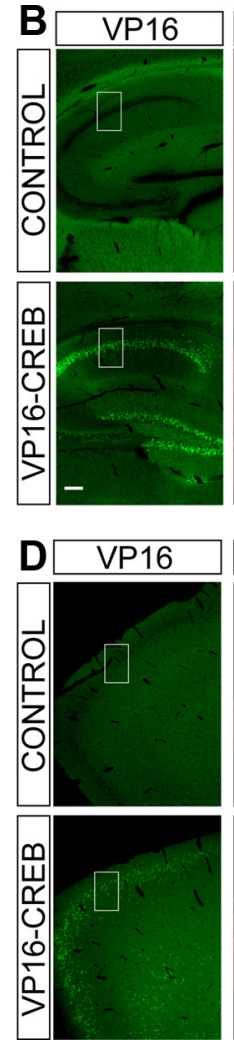
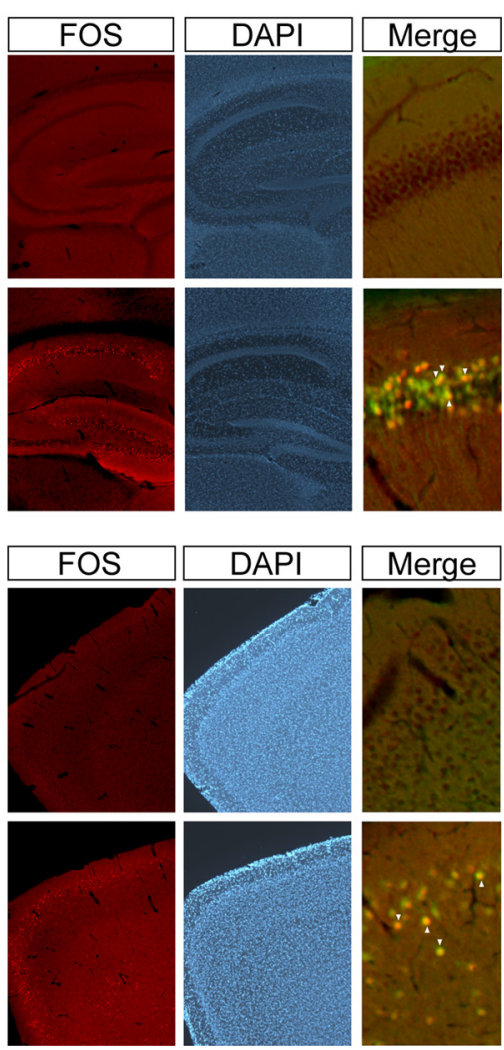

Figure 5. Electrode location and transgene expression. $\boldsymbol{A}$, Photomicrographsillustrating the location (white arrows) of the stimulating (1) and recording (2) sites. Scale bars, $100 \mu \mathrm{m}$. DG, Dentate gyrus; D, dorsal; L, lateral; M, medial; V, ventral. $\boldsymbol{B}-\boldsymbol{D}$, Representative images of the double immunostaining of brain slices from animals used in the experiments described in Figures $1-3$. We used antibodies against the VP16 domain in VP16 -CREB (green) and c-fos (red), a well-characterized CREB target gene. Slices were counterstained using DAPI (blue). Strong expression of VP16 -CREB and activation of downstream targets were observed in the (A1 and DG areas of the hippocampus ( $\boldsymbol{B})$, in striatum ( $\boldsymbol{C}$ ), and in specific layers of the cortex, including the premotor and motor area ( $\boldsymbol{D})$. Merge images (red and green channels) in the right panels of $\boldsymbol{B}-\boldsymbol{D}$ correspond to the inset region labeled with a white square in the left panels. Arrowheads indicate examples of costained cells. Scale bar, $150 \mu \mathrm{m}$.

significantly larger than values collected during habituation sessions $\left(F_{(16,144)}=5.11 ; p<0.001\right)$. In mutant mice, the percentage of conditioned responses was significantly different from habituation values $(p>0.01)$ from the fifth to the 10 th conditioning session and from the first to the fourth extinction sessions. However, the percentage of conditioned responses presented by the control group was significantly larger than that of the mutant group from the third to the 10th conditioning session and for two extinction sessions ( $p<0.001$; Fig. $6 F$, asterisks), indicating that this form of associative learning was impaired in VP16-CREB mice.

In agreement with the impaired performance in the eyeblink task, we found that electrical stimulation of Schaffer collaterals $300 \mathrm{~ms}$ after CS presentation evoked an fEPSP in the CA1 area that was also impaired in VP16-CREB animals (Fig. 6G). In control mice, the slope of the evoked fEPSPs increased steadily over the course of conditioning and was significantly larger than values collected during the two habituation sessions from the fourth to the 10th conditioning sessions and during the first two extinction sessions $\left(F_{(16,153)}=2.25 ; p<0.01\right)$. In contrast, in mutant mice, the slope of fEPSPs evoked at the CA3-CA1 synapse did not show significant changes across the conditioning and extinction sessions $\left(F_{(16,153)}=1.15 ; p=0.32\right)$. In fact, fEPSPs evoked at the CA3-CA1 synapse in control animals were significantly larger across the successive conditioning and extinction sessions than values collected from VP16-CREB mice $(p<0.05$; Fig. $6 G$, asterisks). Importantly, the electrical stimulation of Schaffer collaterals during classical conditioning sessions did not affect the electro-cortical activity recorded extracellularly in the hippocampal CA1 area. As shown in Figure 6C, the regular theta rhythm present in the CA1 area reappeared in phase after the fEPSP evoked by the electrical stimulation of Schaffer collaterals. Moreover, a spectral analysis of extracellular hippocampal recordings collected from control and mutant mice indicates no significant differences in their power spectra $\left(p=0.23, \chi^{2}\right.$ distributed test) and the absence of abnormal EEG activities (e.g., large spikes). As reported previously (Gruart et al., 2006), the slope of fEPSPs evoked by the stimulation of Schaffer collaterals (60 times per day) is stable ( $<10 \%$ variation) across the maximum period of time used here for classical conditioning $(17 \mathrm{~d})$, indicating that electrical stimulation per se, at this low rate, does not modify fEPSP profiles across time.

These deficits in the acquisition of conditioned eyeblink responses and in the expression of the concomitant increase in CA3-CA1 synaptic strength could be caused by the sustained activation of the CREB activity achieved in bitransgenic animals conversely to the transient activation of CREB associated with normal learning. To check this hypothesis, we repeated the same experiment, but dox was removed from the mouse diet the day before starting habituation (compare schemes in Figs. 6A, 7A). As shown in Figure $7 B$, the percentage of conditioned eyelid responses reached significantly $\left(F_{(15,120)}=4.323 ; p=0.045\right)$ larger values than the control group by the eighth conditioning session and then started to decline. Interestingly enough, this larger amount in conditioned responses was paralleled by a concomitant significant $\left(F_{(15,120)}=1.915 ; p=0.043\right)$ increase in the slope 
A

\begin{tabular}{|c|c|c|c|}
\hline 1 & 7 & & \\
\hline$\uparrow$ & Hab. & Conditioning & Extinction \\
\hline
\end{tabular}

B

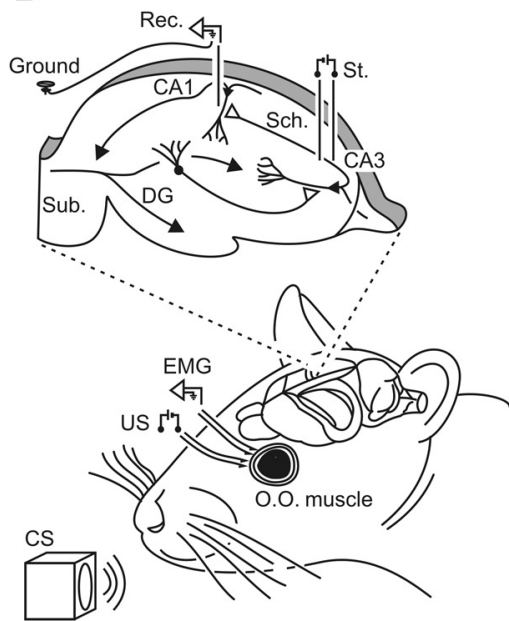

D
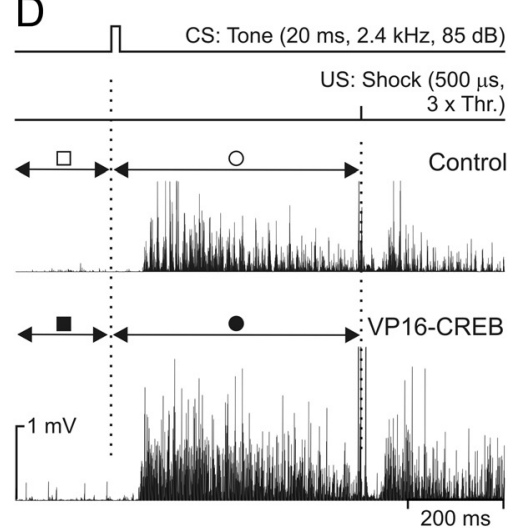

$\mathrm{F}$

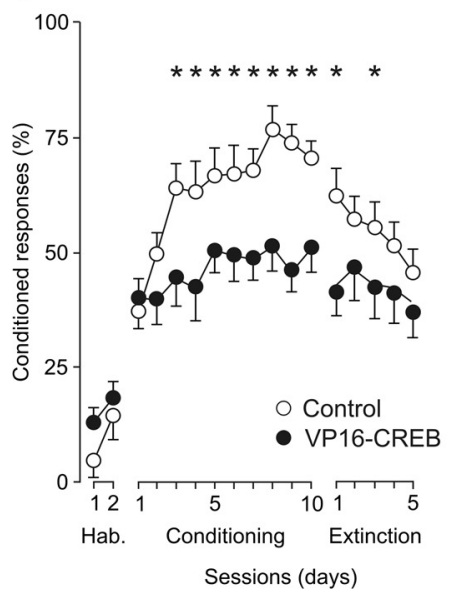

C

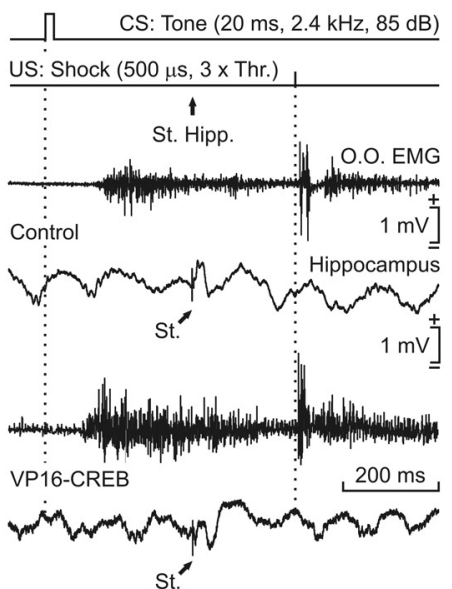

$E$

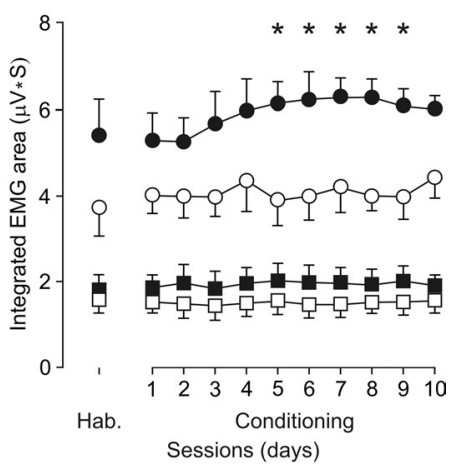

G

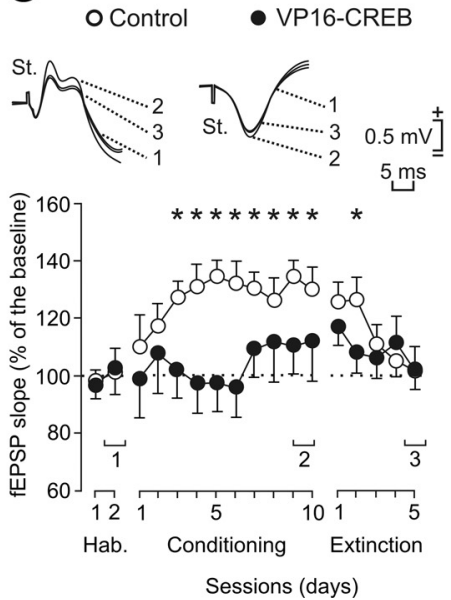

Figure 6. Evolution of CA3-CA1 synaptic field potentials and eyeblink conditioning learning in VP16-CREB mice. A, Schematic representation of this classical eyeblink conditioning experiment. Top lines indicate the time of gene induction and conditioning. $\boldsymbol{B}$, Animals were implanted with hippocampal stimulating (St.) electrodes in the right Schaffer collaterals (Sch.) and recording (Rec.) electrodes in the ipsilateral pyramidal CA1 area. Additional EMG recording electrodes were also implanted in the left orbicularis oculi (0.0.) muscle and stimulating electrodes on the ipsilateral supraorbital nerve. A tone was used as $C S$, and an electric shock at the trigeminal nerve served as US. C, From top to bottom are illustrated the conditioning paradigm, and representative orbicularis oculi, EMG, and hippocampal recordings during paired CS-US presentations for control and mutant (VP16CREB) mice. The time of stimulus presentation to Schaffer collaterals (St. Hipp.) is indicated, as are the times of presentation of CS

of fEPSPs evoked at the hippocampal CA3-CA1 synapse (Fig. 7C). The time window for this facilitation of learning was very narrow, because the facilitation effects were reversed into depression for both conditioned responses $(p \leq 0.004)$ and fEPSP slopes ( $p \leq 0.05)$ from the 11th session onward (Fig. $7 B, C$ ). Together, the two eyeblink conditioning experiments revealed a clear association between deficits in conditioning learning and the absence of activity-dependent changes in synaptic strength in hippocampal synapses and highlighted the relevance of proper timing and duration of CREB activation in this type of learning.

\section{Discussion}

All previous electrophysiological studies in the Schaffer collateral pathway, using either loss- or gain-of-function approaches to manipulate CREB activity, were performed in acute brain slices. Here, we present the first analysis of the consequences of enhanced CREB activity in LTP in this pathway evoked in behaving mice. Our results confirm the enhanced LTP phenotype observed in brain slices of transgenic mice or virally transduced rats expressing caCREB. Furthermore, recordings in behaving animals performing

$\leftarrow$

and US (dotted lines). Data shown were collected during the ninth conditioning session. $\boldsymbol{D}, \boldsymbol{E}$, Quantification of the integrated EMG areas from the two groups ( $n=10$ per group) of animals for spontaneous activity (control, white squares; mutant, black squares) and for evoked conditioned responses (control, white circles; mutants, black circles). Spontaneous EMG activities were collected from the $200 \mathrm{~ms}$ preceding CS presentation. Although no significant differences $(p=0.23)$ were observed in the rectified EMG activities of the orbicularis oculi muscle collected before CS presentations, note the larger EMG areas presented by conditioned responses collected from mutant mice. ${ }^{*} p<0.05$. $\boldsymbol{F}$, Percentage of conditioned eyelid responses reached by the two experimental groups. The values presented by control mice (white circles) were significantly $(p<0.01)$ larger (from the $3 r d$ to the 10th conditioning sessions and for 2 of the extinction sessions) than those reached by mutant mice (VP16-CREB; black circles), indicating that this associative learning was impaired by the chronic activation of CREB. G, Evolution of fEPSPs evoked at the CA3-CA1 synapse across conditioning for control (white circles) and mutant (VP16-CREB; black circles) mice. fEPSP slopes are expressed as a percentage of fEPSP slope recorded during habituation sessions for each of the two groups. Differences in fEPSP slopes between control and mutant groups were statistically significant from the fourth to the 10 th conditioning sessions and for two extinction sessions $\left({ }^{*} p<0.05\right)$, indicating that activity-dependent synaptic plasticity was severely impaired in mutant mice. The top insets show representative fEPSPs (averaged 5 times) collected from control (white circle) and mutant (VP16-CREB; black circle) mice during the second habituation (1), ninth conditioning (2), and fifth extinction (3) sessions. 
A

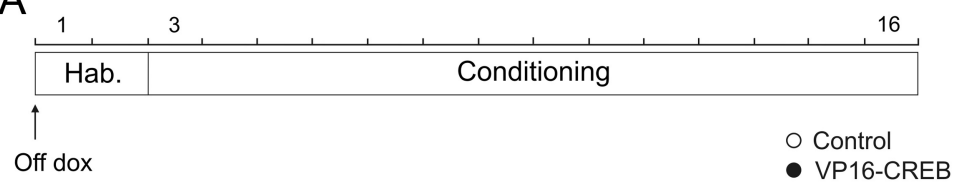
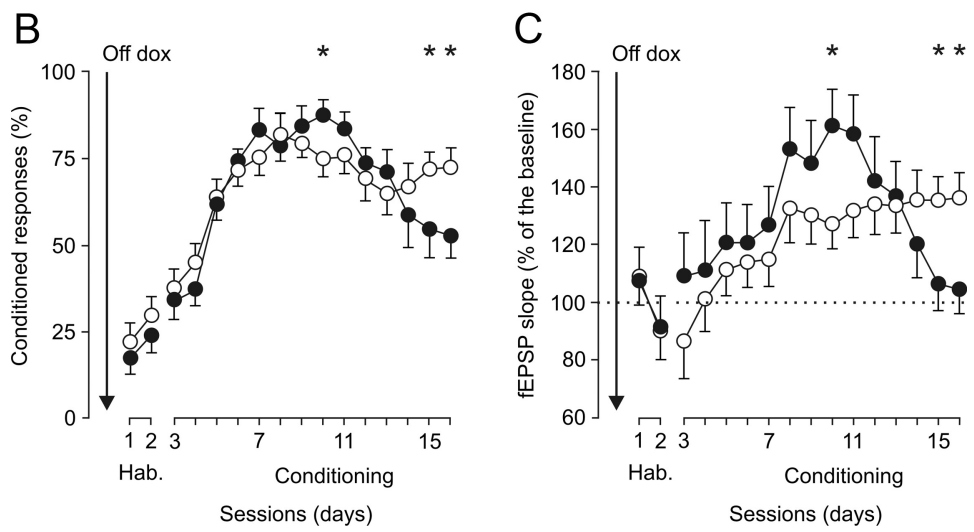

Figure 7. Transient improvement of classical conditioning of eyelid responses in VP16 -CREB mice. $\boldsymbol{A}$, Schematic representation of the experimental design. $\boldsymbol{B}, \boldsymbol{C}$, Evolution of the percentage of conditioned eyelid responses $(\boldsymbol{B})$ and of $\mathrm{fEPSP}$ s evoked at the CA3-CA1 synapse $(\boldsymbol{C})$ after transgene activation the day proceeding the first habituation session (arrow). Note the earlier and significant $\left({ }^{*} p \leq 0.05\right)$ increase in the percentage of conditioned responses $(\boldsymbol{A})$ and in fEPSP slopes $(\boldsymbol{B})$ observed in mutant mice, as well as the late significant depression for both parameters ( $n=10$ mice per group; $\left.{ }^{*} p \leq 0.05\right)$.

an associative learning task-trace eyeblink conditioning-revealed that the enhancement of CREB activity caused larger conditioned responses and transiently facilitated the acquisition of the task and the concurrent potentiation of hippocampal CA3CA1 synapses, although its chronic activation interfered with conditioning.

Previous CREB gain-of-function studies have consistently demonstrated that the activation of this transcription factor can be sufficient to enhance LTP. Transgenic mice (Barco et al., 2002; Alarcon et al., 2006; Suzuki et al., 2011) and virus-transduced animals (Marie et al., 2005; Marchetti et al., 2011) that express caCREB variants have a lower threshold for the induction of L-LTP. Those studies also identified some downstream effector molecules, such as the neurotrophin BDNF and NMDAR (Barco et al., 2005; Marie et al., 2005; Suzuki et al., 2011), that mediate this facilitation. A number of recent studies (Dong et al., 2006; Han et al., 2006; Lopez de Armentia et al., 2007; Viosca et al., 2009a; Zhou et al., 2009) have shown that CREB activity also regulates the intrinsic excitability of neurons (Benito and Barco, 2010). Our in vivo experiments are in agreement with both observations: whereas I/O curves suggest an enhanced excitability, the LTP experiments show an increase of LTP resembling that observed in slices. However, these in vivo experiments also revealed significant differences with previous in vitro studies. In particular, the in vivo experiments showed a differential effect on PPF evoked by HFS in the two groups of animals and alterations in I/O curves that were not detected in slices (Barco et al., 2002). This difference could be explained by the greater sensitivity of in vivo recordings to detect changes in these parameters. The observed changes in PPF may be indicative of a selective modification in the probability of a release of neurotransmitter at the presynaptic terminal in mutant versus control animals (Thomson, 2000; Fernández de Sevilla et al., 2002; Zucker and Regehr, 2002; Andreescu et al., 2007; Lauri et al., 2007). According to the present results (Fig. $3 B$ ), the PPF evoked in control animals during baseline recording was larger (although not significantly dif- ferent) in VP16-CREB mice. As reported previously by Madroñal et al. (2009) in control mice, HFS evokes an early decrease in PPF that is followed by a slow return (in days) to control values, an event not observed in bitransgenic mice. Thus, by the end of the first recording session after LTP induction, PPF was reduced to $\sim 200 \%$ in control animals, whereas mutant animals still presented a value similar to that before LTP ( 400\%). These experiments therefore provide evidence of alterations in presynaptic mechanisms involved in the generation of LTP responses in mutant mice and which escaped previous analyses performed in hippocampal slices (Barco et al., 2002). Because VP16CREB is not expressed in CA3 neurons (Fig. $5 B$ ), this presynaptic effect could be mediated by the release of BDNF accumulated in postsynaptic spines of CA1 neurons. This neurotrophin has been proposed as a retrograde messenger between the postsynaptic and the presynaptic neuron (Magby et al., 2006), and it is known to be upregulated in CA1 neurons of VP16-CREB mice (Barco et al., 2005). In addition, present results indicate that HFS (when applied at $50 \%$ of asymptotic values) evokes larger and longer-lasting LTP in bitransgenic animals than in their littermate controls, suggesting the presence of significant functional changes at postsynaptic sites. We have also shown that these effects are reversible, switching on or off the facilitation of plasticity depending on CREB activity levels.

Our results differ from those reported in a recent study investigating the effect of boosting CREB-dependent transcription in dentate gyrus granule cells in vivo via viral-mediated expression of caCREB and which found an increase in LTP at the medial perforant pathway in the absence of significant changes in I/O curves and PPF (Marchetti et al., 2011). However, it should be noted that LTP in the Schaffer collateral and the medial perforant pathway relies on different mechanisms, so that the impact of the chronic enhancement of CREB expression may differ.

CREB phosphorylation and CREB-dependent transcription are observed in specific neuronal populations during learning processes (Impey et al., 1998; Taubenfeld et al., 1999; Porte et al., 2008). Besides this correlative evidence, a large number of genetic studies support a direct role of CREB in memory formation (Barco and Marie, 2011). In particular, gain-of-function approaches have revealed a variety of effects, from detrimental to beneficial, indicating that the timing, location, and duration of CREB activation are important for normal memory formation. The analysis of transgenic lines expressing CREB variants $\left(\mathrm{CREB}_{\mathrm{Y} 134 \mathrm{~F}}\right.$ and $\left.\mathrm{CREB}_{\text {DIEDML }}\right)$ with a reduced threshold for activation in the forebrain (Suzuki et al., 2011), and rats or mice transduced with CREB overexpressing viruses (Brightwell et al., 2007; Restivo et al., 2009; Sekeres et al., 2010), have demonstrated that enhanced CREB activity can improve long-term memory in different tasks, including social recognition memory, passive avoidance, contextual fear conditioning, and spatial navigation in the water maze. However, these enhanced memories are not necessarily of better quality. Thus, virus-transduced animals overexpressing CREB activity in the auditory thalamus exhibited 
more fear memory but broader auditory fear generalization (Han et al., 2008).

In agreement with the memory-enhancing effects of caCREB, previous work on VP16-CREB mice has demonstrated that the chronic activation of CREB-dependent gene expression in fear memory circuits of these animals bypassed the requirement for $d e$ novo gene expression associated with long-term fear memory formation (Viosca et al., 2009a). However, this strain also showed defects in more complex memory tasks, such as the Morris water maze, in which we found that transgene expression selectively interfered with memory retrieval (Viosca et al., 2009b). It should be noted that, in contrast to the other CaCREB variants referred to above, VP16-CREB can effectively decouple CREB-dependent transcription from upstream signaling cascades that both activate CREB by phosphorylation and shut down its activity in response to feedback mechanisms. This lack of modulation may explain the detrimental effects on memory observed after sustained transgene expression in VP16-CREB transgenics but not in mice overexpressing wild-type CREB or expressing milder caCREB variants. Here, we extended this behavioral analysis and found that performance in a different hippocampal-dependent memory task - trace conditioning of eyelid responses-was initially improved but later impaired by the chronic enhancement of CREB activity.

Whereas the initial higher rate of conditioned response in mutant mice and the concomitant increase in the slope of fEPSPs evoked at the hippocampal CA3-CA1 synapse correlated well with the facilitation of L-LTP observed both in vitro (Barco et al., 2002) and in vivo, the poor performance observed at later times might be a consequence of impaired coordination of different neuronal circuits underlying this behavior and resemble the retrieval deficits reported for the water-maze task (Viosca et al., 2009b). Associative learning is a timed set of simultaneous and successive activations of different neural circuits. In particular, trace conditioning of eyelid responses requires the participation of the cerebellum, the hippocampus, and associated sensory and motor pathways (Christian and Thompson, 2003). Importantly, the transgenic strain investigated here shows enhanced CREBdependent gene expression in key components of this circuit, such as the hippocampus and the motor cortex (Fig. 5), areas identified as brain structures involved in the generation of conditioned eyelid responses (Jiménez-Díaz et al., 2006; LópezRamos et al., 2007). Eyeblink conditioning experiments have demonstrated that changes in the excitability of neurons in the motor cortex may modulate the amplitude of the EMG response to the CS during CS-US pairing (Woody et al., 1974). $\mathrm{Ca}^{2+}$ / calmodulin kinase, a kinase upstream of CREB, was proposed as a mediator of this increase in excitability (Woody et al., 1984). The central nucleus of the amygdala, which also shows transgene expression and enhanced excitability in VP16-CREB mice (Viosca et al., 2009a), can also contribute to regulate the amplitude of the eyeblink (Whalen and Kapp, 1991). Therefore, VP16CREB-driven changes in neuronal excitability and plasticity at different components of this circuit may explain both the larger conditioned responses observed in these animals and the uncoupling between conditioned responses and the strengthening of hippocampal synapses.

Classical genetic experiments in Drosophila first identified the cAMP-CREB pathway as a critical component of the molecular network underlying learning and memory and revealed that both the disruption and the chronic activation of this signaling cascade can interfere with memory formation (Dudai et al., 1976). Our electrophysiological experiments in behaving VP16-CREB transgenic mice further support the critical role of CREB-dependent gene expression in plasticity and memory and demonstrate, like a number of previous studies in other genetically modified mouse strains, that enhanced hippocampal LTP in response to HFS is not necessarily associated with better performance in hippocampal-dependent tasks. Our conditioning experiments suggest that changes in CREB activity occur during learning, but the timing and duration of these changes are tightly regulated and deviation of this sequence can disrupt the learning process.

\section{References}

Alarcon JM, Barco A, Kandel ER (2006) Capture of the late phase of longterm potentiation within and across the apical and basilar dendritic compartments of CA1 pyramidal neurons: synaptic tagging is compartment restricted. J Neurosci 26:256-264. CrossRef Medline

Andreescu CE, Milojkovic BA, Haasdijk ED, Kramer P, De Jong FH, Krust A, De Zeeuw CI, De Jeu MT (2007) Estradiol improves cerebellar memory formation by activating estrogen receptor $\beta$. J Neurosci 27:10832-10839. CrossRef Medline

Barco A, Marie H (2011) Genetic approaches to investigate the role of CREB in neuronal plasticity and memory. Mol Neurobiol 44:330-349. CrossRef Medline

Barco A, Alarcon JM, Kandel ER (2002) Expression of constitutively active CREB protein facilitates the late phase of long-term potentiation by enhancing synaptic capture. Cell 108:689-703. CrossRef Medline

Barco A, Patterson SL, Alarcon JM, Gromova P, Mata-Roig M, Morozov A, Kandel ER (2005) Gene expression profiling of facilitated L-LTP in VP16-CREB mice reveals that BDNF is critical for the maintenance of LTP and its synaptic capture. Neuron 48:123-137. CrossRef Medline

Benito E, Barco A (2010) CREB's control of intrinsic and synaptic plasticity: implications for CREB-dependent memory models. Trends Neurosci 33: 230-240. CrossRef Medline

Bliss TV, Gardner-Medwin AR (1973) Long-lasting potentiation of synaptic transmission in the dentate area of the unanaesthetized rabbit following stimulation of the perforant path. J Physiol 232:357-374. Medline

Brightwell JJ, Smith CA, Neve RL, Colombo PJ (2007) Long-term memory for place learning is facilitated by expression of cAMP response elementbinding protein in the dorsal hippocampus. Learn Mem 14:195-199. CrossRef Medline

Christian KM, Thompson RF (2003) Neural substrates of eyeblink conditioning: acquisition and retention. Learn Mem 10:427-455. CrossRef Medline

Dong Y, Green T, Saal D, Marie H, Neve R, Nestler EJ, Malenka RC (2006) CREB modulates excitability of nucleus accumbens neurons. Nat Neurosci 9:475-477. CrossRef Medline

Dudai Y, Jan YN, Byers D, Quinn WG, Benzer S (1976) Dunce, a mutant of Drosophila deficient in learning. Proc Natl Acad Sci U S A 73:1684-1688. CrossRef Medline

Fernández de Sevilla D, Cabezas C, de Prada AN, Sánchez-Jiménez A, Buño W (2002) Selective muscarinic regulation of functional glutamatergic Schaffer collateral synapses in rat CA1 pyramidal neurons. J Physiol 545: 51-63. CrossRef Medline

Gruart A, Muñoz MD, Delgado-García JM (2006) Involvement of the CA3 CA1 synapse in the acquisition of associative learning in behaving mice. J Neurosci 26:1077-1087. CrossRef Medline

Gureviciene I, Ikonen S, Gurevicius K, Sarkaki A, van Groen T, Pussinen R, Ylinen A, Tanila H (2004) Normal induction but accelerated decay of LTP in APP + PS1 transgenic mice. Neurobiol Dis 15:188-195. CrossRef Medline

Han JH, Yiu AP, Cole CJ, Hsiang HL, Neve RL, Josselyn SA (2008) Increasing CREB in the auditory thalamus enhances memory and generalization of auditory conditioned fear. Learn Mem 15:443-453. CrossRef Medline

Han MH, Bolaños CA, Green TA, Olson VG, Neve RL, Liu RJ, Aghajanian GK, Nestler EJ (2006) Role of cAMP response element-binding protein in the rat locus ceruleus: regulation of neuronal activity and opiate withdrawal behaviors. J Neurosci 26:4624-4629. CrossRef Medline

Impey S, Smith DM, Obrietan K, Donahue R, Wade C, Storm DR (1998) Stimulation of cAMP response element (CRE)-mediated transcription during contextual learning. Nat Neurosci 1:595-601. CrossRef Medline

Jancic D, Lopez de Armentia M, Valor LM, Olivares R, Barco A (2009) Inhibition of cAMP response element-binding protein reduces neuronal 
excitability and plasticity, and triggers neurodegeneration. Cereb Cortex 19:2535-2547. CrossRef Medline

Jiménez-Díaz L, Sancho-Bielsa F, Gruart A, Lopéz-García C, Delgado-García JM (2006) Evolution of cerebral cortex involvement in the acquisition of associative learning. Behav Neurosci 120:1043-1056. CrossRef Medline

Kugelberg E (1952) Facial reflexes. Brain 75:385-396. CrossRef Medline

Lauri SE, Palmer M, Segerstrale M, Vesikansa A, Taira T, Collingridge GL (2007) Presynaptic mechanisms involved in the expression of STP and LTP at CA1 synapses in the hippocampus. Neuropharmacology 52:1-11. CrossRef Medline

Lonze BE, Ginty DD (2002) Function and regulation of CREB family transcription factors in the nervous system. Neuron 35:605-623. CrossRef Medline

Lopez de Armentia M, Jancic D, Olivares R, Alarcon JM, Kandel ER, Barco A (2007) cAMP response element-binding protein-mediated gene expression increases the intrinsic excitability of CA1 pyramidal neurons. J Neurosci 27:13909-13918. CrossRef Medline

López-Ramos JC, Yi PJ, Eleore L, Madroñal N, Rueda A, Delgado-García JM (2007) Classical eyeblink conditioning during acute hypobaric hypoxia is improved in acclimatized mice and involves Fos expression in selected brain areas. J Appl Physiol 103:1479-1487. CrossRef Medline

Madroñal N, Delgado-García JM, Gruart A (2007) Differential effects of long-term potentiation evoked at the CA3 CA1 synapse before, during, and after the acquisition of classical eyeblink conditioning in behaving mice. J Neurosci 27:12139-12146. CrossRef Medline

Madroñal N, Gruart A, Delgado-García JM (2009) Differing presynaptic contributions to LTP and associative learning in behaving mice. Front Behav Neurosci 3:7. CrossRef Medline

Magby JP, Bi C, Chen ZY, Lee FS, Plummer MR (2006) Single-cell characterization of retrograde signaling by brain-derived neurotrophic factor. J Neurosci 26:13531-13536. CrossRef Medline

Marchetti C, Tafi E, Marie H (2011) Viral-mediated expression of a constitutively active form of cAMP response element binding protein in the dentate gyrus increases long term synaptic plasticity. Neuroscience 190: 21-26. CrossRef Medline

Marie H, Morishita W, Yu X, Calakos N, Malenka RC (2005) Generation of silent synapses by acute in vivo expression of CaMKIV and CREB. Neuron 45:741-752. CrossRef Medline

Mayford M, Bach ME, Huang YY, Wang L, Hawkins RD, Kandel ER (1996) Control of memory formation through regulated expression of a CaMKII transgene. Science 274:1678-1683. CrossRef Medline

Paxinos G, Franklin KB (2004) The mouse brain in stereotaxic coordinates, Compact Ed 2. Amsterdam: Elsevier Academic.

Pittenger C, Huang YY, Paletzki RF, Bourtchouladze R, Scanlin H, Vronskaya S, Kandel ER (2002) Reversible inhibition of CREB/ATF transcription factors in region CA1 of the dorsal hippocampus disrupts hippocampusdependent spatial memory. Neuron 34:447-462. CrossRef Medline

Porras-García E, Cendelin J, Domínguez-del-Toro E, Vozeh F, DelgadoGarcía JM (2005) Purkinje cell loss affects differentially the execution, acquisition and prepulse inhibition of skeletal and facial motor responses in Lurcher mice. Eur J Neurosci 21:979-988. CrossRef Medline

Porte Y, Buhot MC, Mons NE (2008) Spatial memory in the Morris water maze and activation of cyclic AMP response element-binding (CREB) protein within the mouse hippocampus. Learn Mem 15:885-894. CrossRef Medline

Restivo L, Tafi E, Ammassari-Teule M, Marie H (2009) Viral-mediated expression of a constitutively active form of CREB in hippocampal neurons increases memory. Hippocampus 19:228-234. CrossRef Medline

Sekeres MJ, Neve RL, Frankland PW, Josselyn SA (2010) Dorsal hippocampal CREB is both necessary and sufficient for spatial memory. Learn Mem 17:280-283. CrossRef Medline

Suzuki A, Fukushima H, Mukawa T, Toyoda H, Wu LJ, Zhao MG, Xu H, Shang Y, Endoh K, Iwamoto T, Mamiya N, Okano E, Hasegawa S, Mercaldo V, Zhang Y, Maeda R, Ohta M, Josselyn SA, Zhuo M, Kida S (2011) Upregulation of CREB-mediated transcription enhances both short- and long-term memory. J Neurosci 31:8786-8802. CrossRef Medline

Taubenfeld SM, Wiig KA, Bear MF, Alberini CM (1999) A molecular correlate of memory and amnesia in the hippocampus [letter]. Nat Neurosci 2:309-310. CrossRef Medline

Thomson AM (2000) Facilitation, augmentation and potentiation at central synapses. Trends Neurosci 23:305-312. CrossRef Medline

Valor LM, Jancic D, Lujan R, Barco A (2010) Ultrastructural and transcriptional profiling of neuropathological misregulation of CREB function. Cell Death Differ 17:1636-1644. CrossRef Medline

Viosca J, Lopez de Armentia M, Jancic D, Barco A (2009a) Enhanced CREBdependent gene expression increases the excitability of neurons in the basal amygdala and primes the consolidation of contextual and cued fear memory. Learn Mem 16:193-197. CrossRef Medline

Viosca J, Malleret G, Bourtchouladze R, Benito E, Vronskava S, Kandel ER, Barco A (2009b) Chronic enhancement of CREB activity in the hippocampus interferes with the retrieval of spatial information. Learn Mem 16:198-209. CrossRef Medline

Whalen PJ, Kapp BS (1991) Contributions of the amygdaloid central nucleus to the modulation of the nictitating membrane reflex in the rabbit. Behav Neurosci 105:141-153. CrossRef Medline

Woody C, Yarowsky P, Owens J, Black-Cleworth P, Crow T (1974) Effect of lesions of cortical motor areas on acquisition of conditioned eye blink in the cat. J Neurophysiol 37:385-394. Medline

Woody CD, Alkon DL, Hay B (1984) Depolarization-induced effects of $\mathrm{Ca}^{2+}$-calmodulin-dependent protein kinase injection, in vivo, in single neurons of cat motor cortex. Brain Res 321:192-197. CrossRef Medline

Zhou Y, Won J, Karlsson MG, Zhou M, Rogerson T, Balaji J, Neve R, Poirazi P, Silva AJ (2009) CREB regulates excitability and the allocation of memory to subsets of neurons in the amygdala. Nat Neurosci 12:14381443. CrossRef Medline

Zucker RS, Regehr WG (2002) Short-term synaptic plasticity. Annu Rev Physiol 64:355-405. CrossRef Medline 